\title{
Dual effects of entomopathogenic fungi on control of the pest Lobesia botrana and the pathogenic fungus Eutypella microtheca on grapevine
}

Juan Aguilera-Sammaritano ${ }^{* *} \mathbb{C}$, Juan Caballero², María Deymié2 ${ }^{2}$ Melisa Rosa ${ }^{3}$, Fabio Vazquez ${ }^{2}$, Delia Pappano ${ }^{3}$, Bernardo Lechner ${ }^{4}$ and Marcia González-Teuber ${ }^{1}$

\begin{abstract}
Background: Entomopathogenic fungi (EPF) are the natural enemies of insect pests. Nevertheless, research on the use of EPF for simultaneous prevention of pest and disease agents on the same crop is limited. In this study, we explored the potential dual effects of three strains of the EPF Metarhizium anisopliae on the control of detrimental agents of Vitis vinifera L., including different developmental stages (larvae, pupae, and adult) of the insect pest Lobesia botrana and the phytopathogenic fungus Eutypella microtheca.
\end{abstract}

Methods: Laboratory pathogenicity trials were performed to examine the effects of the three M. anisopliae strains on the mortality rate of L. botrana. In addition, field trials were conducted to assess the biocontrol potential of one selected $M$. anisopliae strain on the larval stage of L. botrana. Moreover, inhibitory effects of the three EPF strains on $E$. microtheca growth were examined in vitro.

Results: All the M. anisopliae strains were highly effective, killing all stages of L. botrana as well as inhibiting the growth of E. microtheca. The in vitro mortality of larvae treated with the strains was over $75 \%$, whereas that of treated pupae and adults was over $85 \%$. The three EPF strains showed similar efficacy against larvae and adult stages; nevertheless, pupal mortality was observed to be strain dependent. Mortality of L. botrana larvae ranged from 64 to $91 \%$ at field conditions. Inhibition of E. microtheca growth reached $50 \%$ in comparison to the control.

Conclusions: Our study showed that M. anisopliae strains were highly effective in ensuring control of two different detrimental agents of $V$. vinifera $L$., providing new evidence to support the dual effects of entomopathogenic fungi.

Keywords: Entomopathogenic fungi, European grapevine moth, Eutypella microtheca, Grapevine, Ligninolytic fungus, Lobesia botrana

*Correspondence: jsammaritano@ucsc.cl

1 Departamento de Química Ambiental, Facultad de Ciencias, Universidad Católica de la Santísima Concepción, Concepción, Chile

Full list of author information is available at the end of the article

\section{Background}

The grapevine (Vitis vinifera L.) is one of the most cultivated fruit crops worldwide, with a cultivated area of 7.4 million ha. However, grapevine production is affected by several pests and diseases, resulting in high use of pesticides and chemicals [1-4]. Among the numerous pests and diseases of grapevine, the European grapevine moth (Lobesia botrana Den. and Schiff.) and the ligninolytic original author(s) and the source, provide a link to the Creative Commons licence, and indicate if changes were made. The images or other third party material in this article are included in the article's Creative Commons licence, unless indicated otherwise in a credit line to the material. If material is not included in the article's Creative Commons licence and your intended use is not permitted by statutory regulation or exceeds the permitted use, you will need to obtain permission directly from the copyright holder. To view a copy of this licence, visit http://creativecommons.org/licenses/by/4.0/. The Creative Commons Public Domain Dedication waiver (http://creativeco mmons.org/publicdomain/zero/1.0/) applies to the data made available in this article, unless otherwise stated in a credit line to the data. 
fungus (Eutypella microtheca Trouillas, W.M. Pitt and Gubler) are of considerable economic importance to vine production worldwide [5].

Lobesia botrana is one of the most relevant pests of vineyards [6]. Although this pest is endemic to the Palearctic Region [7], is economically more important in southern Europe (France, Spain, Italy and the Mediterranean islands) and South America (Argentina and Chile) [8-11], where can cause substantial crop losses from larvae feeding on young flower buds and fruit $[12,13]$. Additionally, ligninolytic fungi, including $E$. microtheca, Phaeomoniella chlamydospora, and the genus Phaeoacremonium [5, 14, 15], are responsible for pathogenic symptoms, such as wood necrosis and/or discolouration, vascular infections, and decay, which are commonly known as grapevine trunk diseases [16]. These two biological agents are highly detrimental to vine production worldwide. While $L$. botrana is one of the most injurious insect pests of table and wine grape production [17], the economic costs caused by the effects of ligninolytic fungi on grape production is estimated to be more than 1.5 billion dollars per year [18].

Conventional methods of preventing and controlling $L$. botrana and ligninolytic fungi involve the use of chemical compounds $[15,19,20]$. Additionally, the management and prevention of L. botrana in vineyards involve mating disruption [21-24]. However, these methods have been ineffective, as this pest continues to proliferate in vineyards. Moreover, the widespread use of chemical products in controlling crop pests and diseases have been widely criticised because of their negative impacts on biodiversity and human health $[25,26]$. To the best of our knowledge, researchers are yet to develop an effective, economic, and eco-friendly method for preventing and managing L. botrana infestation and E. microtheca infection. Owing to the negative impacts of synthetic pesticides on the environment, biopesticides such as entomopathogenic fungi (EPF), have been identified as a promising alternative for environmentally friendly pest management programmes [27].

EPF are a group of environmentally safe fungi used for biological control of insects and other arthropod pests of agricultural crops. They comprise a wide range of morphologically, phylogenetically, and ecologically diverse fungal species [28]. A wide range of EPF species have been established as important biocontrol agents in many natural and artificial ecosystems [29], to defend against a large number of insect species [30]. Additionally, recent studies suggest that EPF possess inhibitory actions against some phytopathogenic fungal species [31-34]. Thus, there is growing interest in the use of these organisms in integrated pest management (IPM) programmes [35]. However, research on the use of EPF in the simultaneous prevention and management of several pest and disease agents of the same crop is limited.

Here, we examined the effectiveness of three different strains of the EPF Metarhizium anisopliae in controlling L. botrana at both laboratory and field conditions, as well as growth of E. microtheca in vitro. Therefore, the findings of this study serve as a basis for the use of EPF in pest and disease control providing new evidence for the inclusion of EPF as dual biocontrol agents in vineyards.

\section{Methodology \\ Biological material \\ Entomopathogenic fungal strains}

EPF were obtained from soils under vine crops in San Juan, Argentina ( $31^{\circ} 65^{\prime} 67^{\prime \prime} \mathrm{S}$; $\left.68^{\circ} 58^{\prime} 51^{\prime \prime} \mathrm{W}\right)$. Specimens were isolated from soil samples using the Tenebrio molitor larval baiting technique [36]. Three $M$. anisopliae strains (Metsc.) Sorok. (CEP413, CEP589 and CEP591) were selected for trials based on preliminary inhibitory tests against $L$. botrana [32]. The strains were first identified morphologically [37] and then genetically [38]. The M. anisopliae strains showed cylindrical conidia (between 5 and $9 \mu \mathrm{m}$ of length), with an olive-green colouring, which is characteristic of the species. The isolated EPF were preserved in the Fungal Entomopathogens Collection of the 'Centro de Estudios Parasitológicos y de Vectores' (CEPAVE-CONICET, La Plata, Buenos Aires, Argentina).

\section{Lobesia botrana specimens}

The effects of $M$. anisopliae strains against the fifth instar larvae $\left(\mathrm{L}_{5}\right)$, pupae $\left(\mathrm{P}_{\mathrm{p}}\right)$, and adults $\left(\mathrm{A}_{\mathrm{d}}\right)$ stages of $L$. botrana were examined. Newly emerged larvae were obtained from a breeding colony in Mendoza, Argentina $\left(33^{\circ} 01^{\prime} 52^{\prime \prime} \mathrm{S}, 68^{\circ} 46^{\prime} 34^{\prime \prime} \mathrm{W}\right)$. Fifth instar larvae of $L$. botrana were selected for trials based on previous studies reporting that damage by L. botrana increases with larval age [39]. The larvae were reared on an artificial diet [40], which was provided ad libitum during the complete growth period. Individuals from all stages were maintained in a growth chamber under a 16-h photoperiod, at a temperature of $25 \pm 5{ }^{\circ} \mathrm{C}$, and relative humidity ranging from 30 to $50 \%$. This procedure has been reported to be effective in producing large numbers of larvae [41].

\section{Phytopathogenic fungal strain}

The phytopathogenic fungal strain was obtained from a vine culture $\left(31^{\circ} 76^{\prime} 10^{\prime \prime} \mathrm{S}, 68^{\circ} 57^{\prime} 94^{\prime \prime} \mathrm{W}\right)$ located in San Juan Province, Argentina. Fourteen plants displaying clear symptoms of eutypiosis, including chlorotic and small leaves as well as short, rough internodes, stunted shoots, and dark brown wood with hard wedgeshaped consistency [42], were selected from the field. 
The infected plants were uprooted, and infected tissues were excised and taken to the laboratory. We collected 2-5 subsamples from each symptomatic wood fragment. To remove external non-parasitic microorganisms, the surface of each subsample was sterilised as follows: $30 \mathrm{~s}$ in $70 \%$ ethanol, 2 min in $3.5 \% \mathrm{NaOCl}$, and $30 \mathrm{~s}$ in $70 \%$ ethanol [43]. The subsamples were then cultured in Petri dishes containing malt extract agar medium (MEA) and on plates containing potato glucose agar (PGA) (Britania ${ }^{\circledR}$ ). Both MEA and PGA culture media were supplemented with $100 \mathrm{mg} / \mathrm{mL}$ of streptomycin sulphate, $50 \mathrm{mg} / \mathrm{mL}$ of chlortetracycline $\mathrm{HCl}$, and $5 \mathrm{mg} / \mathrm{mL}$ of dichloran to prevent bacterial and yeast contamination [44]. Plates were immediately cultured in the dark in a growth chamber at $25^{\circ} \mathrm{C}$ and inspected daily over a period of 4 weeks until fresh mycelia were observed. Subsequently, successive isolations were performed to derive pure cultures of the fungal strain.

The identification of the phytopathogenic fungus was based first on morphological observations, followed by molecular identification [45]. Genomic DNA was extracted from the mycelium growing on liquid Peptone Malt (MP) medium at 21 days using a DNeasy UltraCkean Microbial Kit (Qiagen ${ }^{\circledR}$, Germany), following the manufacturer's protocol. Then, the extracted DNA was purified, and the internal transcribed spacer (ITS) region of the complete rDNA (ITS1, ITS2 and 5.8S) was amplified by PCR. The PCR products were sent to Macrogen Inc $^{\odot}$ (Seoul, Korea) for purification and sequencing. The strain CC58 was identified as E. microtheca (SINAVIMO \#9287) and preserved in the Centro de Investigación y Extensión Forestal Andino Patagónico (CIEPFAP) mycological collection, Chubut, Argentina.

\section{EPF control on L. botrana in vitro}

The evaluation of EPF efficacy in vitro and in vivo can be achieved using different application techniques, such as dipping insects in a spore suspension [46, 47], using topical micro-applications [48-51], or spraying EPF formulations directly to the insects or plants $[52,53]$. In this study, EPF pathogenicity across different stages of $L$. botrana was tested using a micro-application technique, which ensures a higher level of precision, accuracy, and reliability of the pest susceptibility [54], and is useful to compare insect susceptibility to EPF among different developmental stages. A laboratory experiment was performed to examine the effects of three EPF strains on the mortality rate of $L$. botrana using $240 \mathrm{fifth}$ instar larvae $\left(\mathrm{L}_{5}\right), 240$ pupae $\left(\mathrm{P}_{\mathrm{P}}\right)$, and 240 adults $\left(\mathrm{A}_{\mathrm{d}}\right)$ of L. botrana using a topical micro-application technique [50]. EPF were applied to un-cocooned pupae $[6,55$, 56]. The experiment comprised four groups: (1) insects treated with EPF strain CEP413, (2) insects treated with
EPF strain CEP589, (3) insects treated with EPF strain CEP591, and (4) control group (insects treated with an EPF-free solution). Treatment groups were topically treated $[50,54]$ with a $1 \mu \mathrm{L}$ drop $\left(1 \times 10^{6} \mathrm{c} / \mathrm{mL}\right)$ of the respective strain using a Hamilton ${ }^{\circledR}$ micro dispenser (7000 Series Syringes $\left.{ }^{\circledR}\right)$. The control group was treated with $1 \mu \mathrm{L}$ of distilled water. Mortality rates were measured using a subset of 20 individuals per replicate. After fungal application, the $\mathrm{L}_{5}, \mathrm{P}_{\mathrm{P}}$, and $\mathrm{A}_{\mathrm{d}}$ of $L$. botrana were carefully transferred to sterile $90-\mathrm{mm}$ Petri dishes lined with sterile filter paper $\left(\right.$ Whatman $\left.{ }^{\circledR}\right)$. Immediately, dishes were incubated in growth chambers at $27^{\circ} \mathrm{C}$. Considering the high competition for food among larvae [57], an artificial diet [40] was offered ad libitum during the study period. Adults were carefully inoculated immediately after pupal eclosion and transferred to plastic trays $(20 \mathrm{~cm} \times 10 \mathrm{~cm} \times 15 \mathrm{~cm})$. The adults were nourished during the experimental period with a $5 \%$ ascorbic acid solution provided using a plastic syringe [41]. Since mortality over long time periods is not representative of field conditions, the mortality rates of $\mathrm{L}_{5}, \mathrm{P}_{\mathrm{p}}$, and $\mathrm{A}_{\mathrm{d}}$ of $L$. botrana were measured up to the 7 th day of the experiment. Dead European grapevine moths were carefully removed from the Petri dish to avoid horizontal transmission. To prevent adults from escaping from the trays, dead individuals were not removed until the end of the experiment. Abbott's equation [58] was used to obtain the corrected mortality $(\mathrm{CM})$.

\section{EPF control on L. botrana in the field}

Efficacy of EPF on the control of the larval stage of $L$. botrana was tested in the field. Based on the corrected mortality (CM) observed in the laboratory experiments, we selected one M. anisopliae strain (CEP591) for field trials. The trial was repeated across different seasons over 1 year (September 2018-March 2019): $\left(S_{1}\right)$ during spring, when plants displayed well developed inflorescences, $\left(S_{2}\right)$ during early summer, when plants had undeveloped bunches, and $\left(\mathrm{S}_{3}\right)$ during late summer, which comprised the vine veraison stage. Trials were carried out in an experimental field ("Las Mellizas") located in San Juan, Argentina ( $31^{\circ} 58^{\prime} 58^{\prime \prime} \mathrm{S}$; $68^{\circ} 26^{\prime} 28^{\prime \prime} \mathrm{W}$ ), which is planted with $V$. vinifera $\mathrm{L}$. cv. Merlot since 2011. The field trial was performed within an approximate area of 4.63 ha. No chemical or biological insecticides were added to vines 45 days before trials or during trials. To avoid pupation during trials, we performed the field experiments with newly emerged $\mathrm{L}_{3}-\mathrm{L}_{4}$ larvae of $L$. botrana. Trials consisted of two treatments (EPF+ and EPF-), with six replicates each treatment. Micro-application technique was used. For the $\mathrm{EPF}+$ treatment, 20 larvae were topically treated with $1 \mu \mathrm{L}$ drop $\left(1 \times 10^{6} \mathrm{c} / \mathrm{mL}\right)$ of CEP591. The control group 
(EPF-) were treated with $1 \mu \mathrm{L}$ of sterile distilled water. After larvae were topically treated, they were immediately brought to the experimental field and carefully placed on selected grapevine bunches in groups of 20 treated individuals per bunch. The grapevine bunches were then immediately covered with a fabric mesh of $500 \times 500 \mu \mathrm{m}$ of pore diameter. Fabric bands were then attached from the top of the mesh to the rachis of each bunch to enclose the experimental unit. This helped to maintain a closed system, preventing the entry or exit of insects into the experimental unit. Treatments were spatially separated by at least $20 \mathrm{~m}$. After 7 days, bunches were carefully removed from plants and transferred to the laboratory in closed plastic containers to determine larvae mortality. Environmental temperature $\left(\mathrm{T}^{\circ}\right)$ and relative humidity $(\mathrm{RH})$ during the three seasons were obtained from an automatic weather station (Davis Instruments ${ }^{\circledR}-$ Mod. Vantage pro-2).

\section{Eutypella microtheca growth assessment}

We examined the inhibitory rate of the three strains of EPF (CEP413, CEP589, and CEP591) on the growth of $E$. microtheca strain (CC58). CC58 was used in this study because it was the most abundant phytopathogenic strain affecting grapevine plants at the study site (see above for detailed geolocation information). CEP413, CEP589, and CEP591 were co-cultured with CC58 in separate Petri dishes containing potato glucose agar (PGA) media (Bri$\left.\operatorname{tania}{ }^{\circledR}\right)$. To achieve this, a 5-mm mycelial disc, obtained from the edges of a 10-days-old culture of CC58, was placed at the centre of a dish containing $20 \mathrm{~mL}$ of PGA. Immediately, four discs of one EPF strain (from 10-daysold cultures) of the same diameter as those of the CC58 strain were placed carefully at four sites at approximately $3 \mathrm{~cm}$ from the centre of the Petri dish [59]. The Petri dishes were inverted to prevent conidia from falling onto the agar medium and then incubated in the dark at $28 \pm 2{ }^{\circ} \mathrm{C}$. The growth of the E. microtheca colony was measured every $96 \mathrm{~h}$ on two perpendicular axes over the following 20 days under a stereomicroscope (Lancet Instruments ${ }^{\circledR}$, Model ZTX-30Y-C2, China) using a digital calliper. The control was determined by measuring the radial growth of $E$. microtheca strain growing in isolation (agar discs without EPF) on separate Petri dishes (indicative of the potential growth of the E. microtheca strain). The percentage of growth inhibition (GI) was calculated with the following formula: GI $(\%)=((\mathrm{A}-\mathrm{B}) / \mathrm{A}) \times 100$, where $A$ represents the radial growth $(\mathrm{mm})$ of the control treatment, and B represents the radial growth $(\mathrm{mm})$ of the pathogen with the EPF setup [60]. Three replicate plates were prepared for each phytopathogenic/EPF strain combination and for the control treatment.

\section{Statistical analyses}

Effects of CEP413, CEP589, and CEP591 on mortality rate of larvae $\left(\mathrm{L}_{5}\right)$, pupae $\left(\mathrm{P}_{\mathrm{p}}\right)$, and adults $\left(\mathrm{A}_{\mathrm{d}}\right)$ of $L$. botrana in vitro were analysed using a one-way ANOVA (independent factor: EPF strains, response variable: corrected mortality $(\mathrm{CM}))$. Efficacy exhibited by CEP591 over L. botrana in the field was analysed using a one-way ANOVA (independent factor: seasons, response variable: $\mathrm{CM}$ ). Antagonistic effects of EPF on E. microtheca growth were also analysed using a one-way ANOVA (independent factor: EPF strains, response variable: pathogen inhibition growth (\%). A post hoc Fisher's LSD test was performed to analyse differences among treatments. All statistical analyses were performed using Infostat ${ }^{\circledR}$ statistical software [61].

\section{Results}

\section{Biological control of EPF on L. botrana in vitro}

All $M$. anisopliae strains tested in this study were able to infect $L$. botrana at any developmental stage, including larvae $\left(\mathrm{L}_{5}\right)$, pupae $\left(\mathrm{P}_{\mathrm{p}}\right)$, and adults $\left(\mathrm{A}_{\mathrm{d}}\right)$ (Fig. 1a-c, respectively). No significant differences were observed among EPF strain efficacy for $\mathrm{L}_{5}(F=0.22, p=0.8097)$ and $\mathrm{A}_{\mathrm{d}}(F=0.12, p=0.8905)$. Nevertheless, for $\mathrm{P}_{\mathrm{p}}$ stage significant differences in EPF strain efficacy were observed ( $F=33.25, p=0.0006)$. CEP591 was observed to be more effective (99.9\%) than CEP589 (81.6\%) and CEP413 (79.98\%) in controlling the pupal stage of $L$. botrana (Fig. 2). Overall, the mortality of the control group was lower than $15 \%$ in all cases.

\section{Biological control of EPF on L. botrana in the field}

At field conditions, larvae of L. botrana were susceptible to EPF infection across all seasons. Nevertheless, $L$. botrana mortality was significantly affected by the season $(F=6.92, p=0.0074)$. Overall, larvae of $L$. botrana were more susceptible to CEP591 at early spring (91\%) and early summer $(81.5 \%)$ than in late summer (Table 1). In late summer, CM drastically decreased to $64.9 \%$. Mortality of control larvae was relatively constant across seasons $(F=1.11, p=0.3551)$, which rounded $5 \%$.

\section{Inhibitory effects of EPF on E. microtheca}

The growth of $E$. microtheca was significantly affected by the EPF strains $(F=151.49, p<0.0001)$. There was a significant decrease in the growth of $E$. microtheca treated with CEP413, CEP589, and CEP591 compared with that of the control group (Fig. 3). The inhibitory percentage of the strain CEP413 $(65.2 \% \pm 12.24)$ was significantly higher than those of CEP591 $(55.07 \% \pm 10.11)$ and 


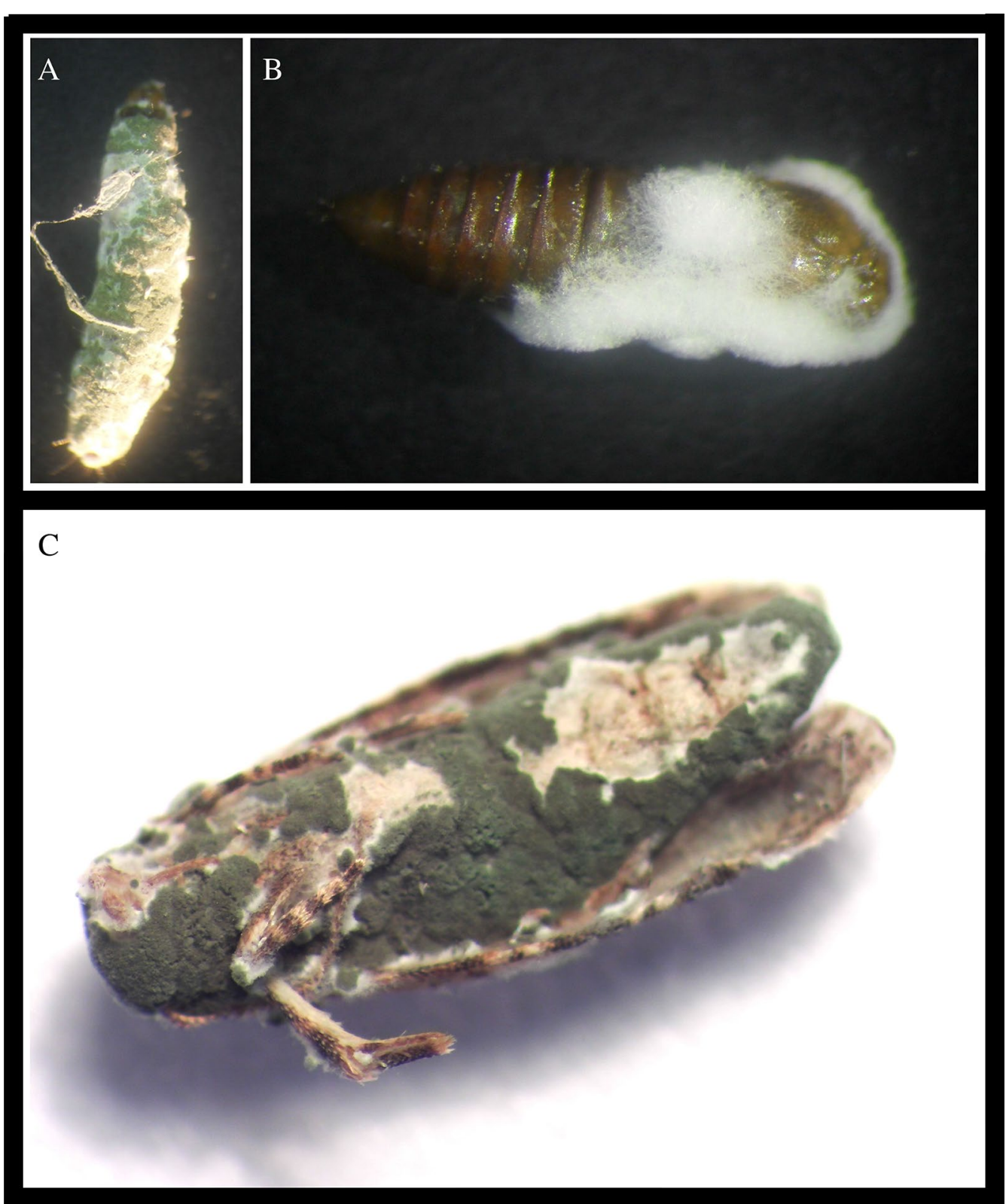

Fig. 1 Effects of the EPF Metarhizium anisopliae on Lobesia botrana. Effective infection of Metarhizium anisopliae strains can be observed for larvae (a), pupae (b), and adults (c)

CEP589 (50.27\% \pm 9.12$)$ on E. microtheca by the end of the trial (after $480 \mathrm{~h})(F=7.8, p=0.0013)$.

\section{Discussion}

Strains of $M$. anisopliae were highly effective to controlling two detrimental agents of $V$. vinifera $L$. in vitro and in vivo. EPF strains showed high mortality rates in all developmental stages of L. botrana and reduced the growth of the phytopathogenic fungus $E$. microtheca.
Overall, the three $M$. anisopliae strains were highly effective to controlling $L$. botrana at the $\mathrm{L}_{5}, \mathrm{P}_{\mathrm{p}}$, and $\mathrm{A}_{\mathrm{d}}$ stages. The average corrected mortality (CM) of larvae treated with the EPF strains was over $75 \%$, while that of treated pupae and adults was over $85 \%$. However, the CM of pupae treated with CEP591 was significantly higher than that with the other two strains, causing approximately $100 \%$ of mortality. This result is particularly important given that the pupal stage is highly resistant to fungal infection, at least in some 


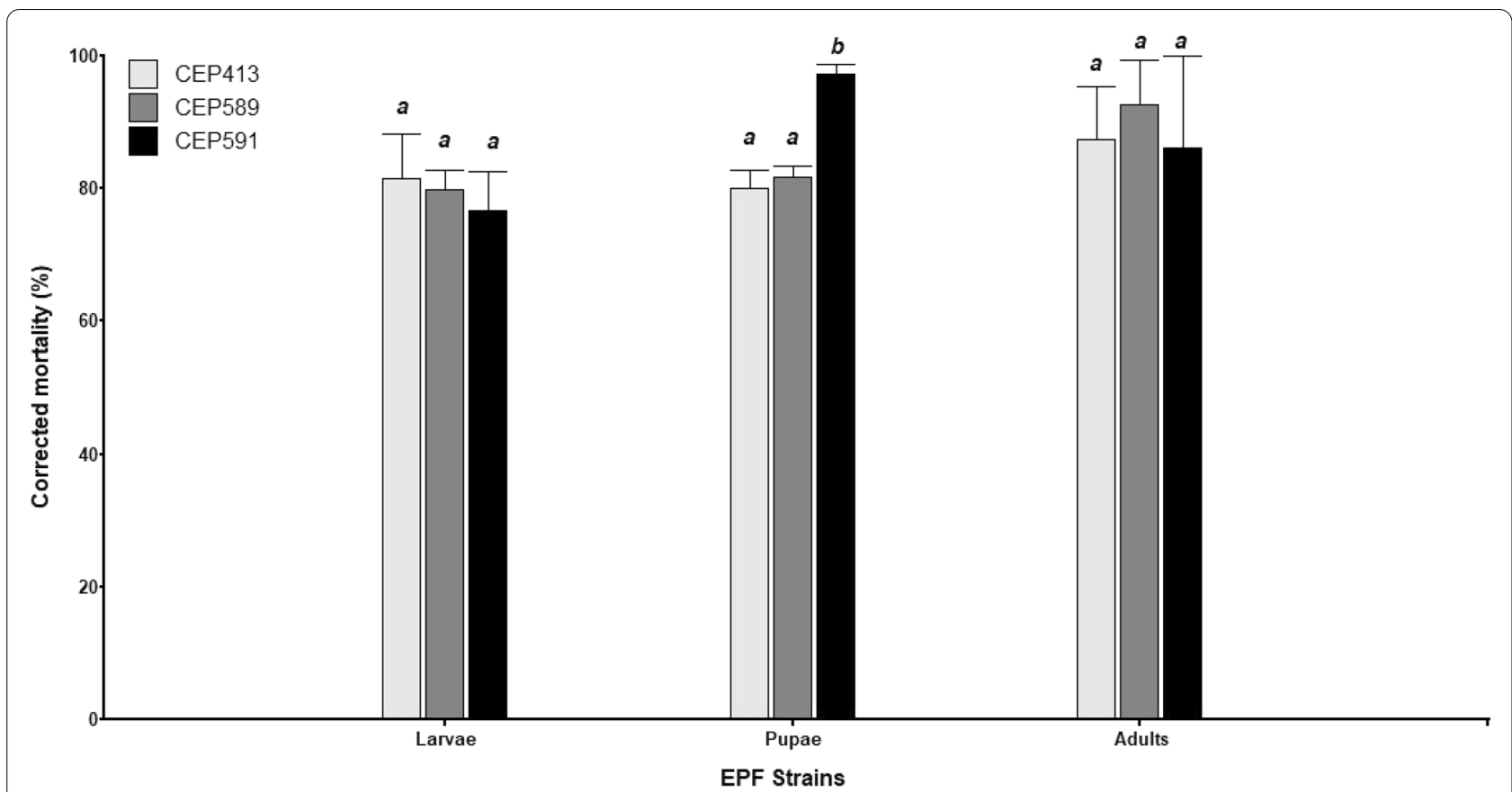

Fig. 2 Corrected mortality (\%) of Lobesia botrana larvae, pupae and adults caused by the three strains of Metarhizium anisopliae (CEP413, CEP589, CEP591). Mean percentages $\pm S D$ (standard deviation) of infected individuals is indicated for three replicates. Different letters indicate significant differences among treatments within each L. botrana stage (Fisher's LSD; $p<0.05$ )

Table 1 Evaluation of EPF at field conditions

\begin{tabular}{lccc}
\hline EPF strain & $\mathbf{C M}(\%)-\mathbf{S}_{\mathbf{1}}$ & $\mathbf{C M}(\%)-\mathbf{S}_{\mathbf{2}}$ & $\mathbf{C M}(\%)-\mathbf{S}_{\mathbf{3}}$ \\
\hline CEP591 & $91 \pm 9.8^{\mathrm{a}}$ & $81.58 \pm 17.53^{\mathrm{a}}$ & $64.97 \pm 6.88^{\mathrm{b}}$ \\
Temperature & $22.5 \pm 1.2^{\circ} \mathrm{C}$ & $25.4 \pm 2.5^{\circ} \mathrm{C}$ & $21.7 \pm 2.1^{\circ} \mathrm{C}$ \\
$\mathrm{RH}$ & $52 \pm 12.2 \%$ & $64 \pm 8.4 \%$ & $61 \pm 3.9 \%$ \\
\hline
\end{tabular}

Corrected mortality $(\mathrm{CM}) \pm \mathrm{SD}$ (standard deviation) for $\mathrm{L}_{3}-\mathrm{L}_{4}$ larvae of Lobesia botrana caused by Metarhizium anisopliae strain CEP591 at field conditions. All trials were performed in vivo (Vitis vinifera L. cv. Merlot) on an experimental field located in San Juan (Argentina) ( $31^{\circ} 58^{\prime} 58^{\prime \prime} \mathrm{S} ; 68^{\circ} 26^{\prime} 28^{\prime \prime}$ W). The trial was initiated at early spring $\left(\mathrm{S}_{1}\right)$ and repeated at early summer $\left(\mathrm{S}_{2}\right)$ and late summer $\left(\mathrm{S}_{3}\right)$, comprising a complete vine productive season. Letter's $a$, $b$ indicates significant differences between seasons (Fisher's LSD; $p<0.05$ )

Lepidoptera [62], Coleoptera [63], and Blattodea [64] species. Consistent with our results, previous studies have also shown the effectiveness of EPF strains in controlling immature stages of $L$. botrana, including larvae and pupae [32]. Similarly, recent findings [65] showed that Metarhizium and Beauveria, which were isolated from soils under vineyards in Argentina, were effective against the fifth-instar larvae of $L$. botrana in vitro. Additionally, several studies have shown that Metarhizium is a successful EPF genus in the biological control of some lepidopteran pests in vitro, such as Spodoptera litura, S. frugiperda, Tuta absoluta, and Plutella xylostella [66-69], suggesting that strains of this genus have the potential to be used as biopesticides against several lepidopteran species.

Previous studies on the effectiveness of EPF strains against $L$. botrana have been particularly focused on a single developmental stage of the insect's life cycle [55, $65,70,71]$. In this study, we have shown the strong effectiveness of $M$. anisopliae strains against different developmental stages of L. botrana, including larvae, pupae, and adults in vitro. These results agree with other studies, which have demonstrated the role of EPF strains as an efficient method controlling all developmental stages of different insect pests such as Megalurothrips sjostedti [72], S. litura [68], Dermanyssus gallinae [73], and Tetranychus urticae [74]. Differences in EPF effectiveness between the larval and pupal stage of $L$. botrana may be associated with differences in the ecdysis time between both stages. Larvae, in contrast to pupae, may have shorter time intervals between successive ecdysis, which has been reported to be an important factor in insect resistance to fungal infection $[75,76]$.

In the field, the strain CEP591 was shown to be effective in killing $L$. botrana larvae across seasons. Nevertheless, efficacy of CEP591 in controlling L. botrana in the field was dependent on the season. In late summer, it was observed that CEP591 was less pathogenic to $L$. botrana, causing a mortality of around $64 \%$ compared to the other two seasons, in which larval mortality ranged 


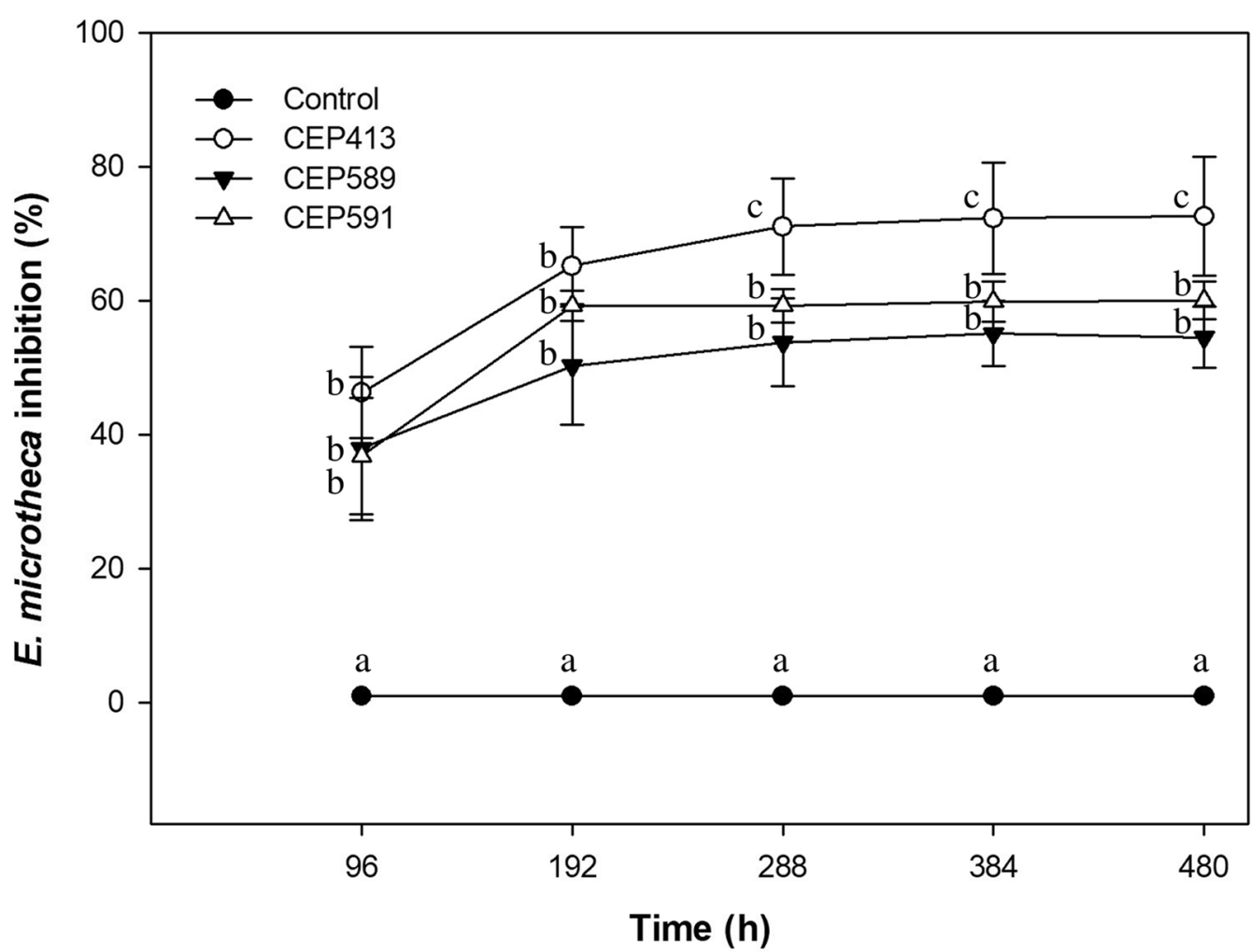

Fig. 3 Growth inhibition (\%) of the phytopathogenic fungus Eutypella microtheca caused by the three strains of Metarhizium anisopliae (CEP413, CEP589, CEP591) over 20 days. Control consisted of agar plugs without fungal spores. Mean percentages \pm SD (standard deviation) is indicated for three replicates. Different letters indicate significant differences among treatments for each measured time (Fisher's LSD; $p<0.05$ )

from 81 to $91 \%$. Our results agree with previous results, which have reported a marked decline in the biocontrol efficacy when insect's pests are challenged by EPF in the field compared to laboratory trials [77-79]. For example, Rodríguez et al. [77] observed that the M. anisopliae dose required to kill $50 \%$ of Varroa destructor (Acari) in vitro was considerably lower $\left(3.8 \times 10^{5} \mathrm{c} / \mathrm{mL}\right)$ to that required under natural conditions $\left(5 \times 10^{10} \mathrm{c} / \mathrm{mL}\right)$. Similar observations were found by Altimira et al. [55] using the EPF Beauveria pseudobassiana to control $L$. botrana in vitro and in vivo. This efficacy variation of EPF in vitro versus in vivo may be associated with abiotic factors, including temperature, relative humidity, and UV radiation, which are known to influence some physiological insect processes such as conidia germination [55, 80, 81].

The results here showed that the three $M$. anisopliae strains were also effective inhibiting the $E$. microtheca growth when co-cultured during 20 days at $28^{\circ} \mathrm{C}$ in the dark. The three tested strains significantly inhibited the growth of E. microtheca by over 50\%. The strain CEP413 was, however, more effective than CEP589 and CEP591 in inhibiting the proliferation and growth of E. microtheca over time. Different EPF species, such as Beauveria bassiana, Metarhizium brunneum, M. anisopliae, Lecanicillium lecanii, and Isaria javanica [33, 34, 82, 83] have been identified as suitable candidates for controlling several phytopathogenic fungi, including Rhizoctonia solani, Pythium myriotylum [84], Sphaerotheca fuliginea [85], and Botrytis cinerea [86]. However, to the best of our records this is the first study reporting an antagonistic effect of $M$. anisopliae over E. microtheca, showing that $M$. anisopliae strains are also appropriate candidates for use in biological control of one of the most important pathogens of $V$. vinifera $\mathrm{L}$.

\section{Conclusions}

The present study revealed that three strains of $M$. anisopliae were highly effective infecting and killing different developmental stages of $L$. botrana in vitro and in vivo. Additionally, the same EPF fungal strains were able to inhibit the growth of the phytopathogen E. microtheca in vitro. Our results showed that $M$. anisopliae strains have the potential to be used in a program of integrated pest management aimed to control different detrimental agents of vines. Additional research, however, is 
required to improve and sustain the efficacy of EPF under natural conditions, particularly under different environmental conditions.

\author{
Abbreviations \\ EPF: Entomopathogenic fungi; IPM: Integrated pest management; MEA: Malt \\ extract agar; PGA: Potato glucose agar; MP: Liquid peptone malt; CM: Cor- \\ rected mortality; $L_{5}$ : Fifth instar larvae; $P_{\mathrm{p}}$ : Pupae; $A_{d}$ : Adults.
}

\section{Acknowledgements}

We thank MsC María Eugenia Herrera from INTA [Luján de Cuyo-Mendoza, Argentina] who provided biological material that greatly assisted the research. Finally, we would also like to show our gratitude to two anonymous reviewers for their insights.

\section{Authors' contributions}

Conceptualisation: JAS, JC, FV; methodology and trials: JAS, JC, MR; Statistical analysis: JAS, BL, MD; writing and revision: JAS, MGT; resources: FV, BL, DP. All authors read and approved the final manuscript.

\section{Funding}

This study was supported by the PICT-2018 Grant \#1 (03062); the FONDECYT Grant \#2 ( $\left.{ }^{\circ} 3190754\right) ;$ and the Programa de Cooperativismo y Economía Social en la Universidad Grant \#3 (UNSJ777).

\section{Availability of data and materials}

Figures, and data sheets are available by request to the corresponding author.

\section{Declarations}

\section{Ethics approval and consent to participate}

Not applicable.

\section{Consent for publication}

Not applicable.

\section{Competing interests}

The authors declare no competing interests. The funders had no role in the design of the study; in the collection, analyses, or interpretation of data; in the writing of the manuscript; or in the decision to publish the results.

\section{Author details}

'Departamento de Química Ambiental, Facultad de Ciencias, Universidad Católica de la Santísima Concepción, Concepción, Chile. ${ }^{2}$ Instituto de Biotecnología, Facultad de Ingeniería, Universidad Nacional de San Juan, San Juan, Argentina. ${ }^{3}$ Instituto de Ciencias Básicas, Facultad de Ingeniería, Universidad Nacional de San Juan, San Juan, Argentina. Instituto de Micología y Botánica, Facultad de Ciencias Exactas y Naturales, Universidad de Buenos Aires, Buenos Aires, Argentina.

Received: 23 May 2021 Accepted: 13 December 2021

Published online: 24 December 2021

\section{References}

1. Čepo DV, Pelajić M, Vrček IV, Krivohlavek A, Žuntar I, Karoglan M. Differences in the levels of pesticides, metals, sulphites and ochratoxin A between organically and conventionally produced wines. Food Chem. 2018;246:394-403.

2. Herrero-Hernández E, Andrades MS, Álvarez-Martín A, Pose-Juan E, Rodríguez-Cruz MS, Sánchez-Martín MJ. Occurrence of pesticides and some of their degradation products in waters in a Spanish wine region. J Hydrol. 2013;486:234-45.

3. Hildebrandt A, Guillamón M, Lacorte S, Tauler R, Barceló D. Impact of pesticides used in agriculture and vineyards to surface and groundwater quality (North Spain). Water Res. 2008;42(13):3315-26.
4. Marsala RZ, Capri E, Russo E, Bisagni M, Colla R, Lucini L, et al. First evaluation of pesticides occurrence in groundwater of Tidone Valley, an area with intensive viticulture. Sci Total Environ. 2020:736:139730.

5. Paolinelli-Alfonso M, Serrano-Gomez C, Hernandez-Martinez R. Occurrence of Eutypella microtheca in grapevine cankers in Mexico. Phytopathol Mediterr. 2015;54(1):86-93

6. Vicente-Díez I, Blanco-Pérez R, Chelkha M, Puelles M, Pou A, CamposHerrera R. Exploring the use of entomopathogenic nematodes and the natural products derived from their symbiotic bacteria to control the grapevine moth, Lobesia botrana (Lepidoptera: Tortricidae). Insects. 2021;12(11):1033.

7. Rank A, Ramos RS, da Silva RS, Soares JRS, Picanço MC, Fidelis EG. Risk of the introduction of Lobesia botrana in suitable areas for Vitis vinifera. J Pest Sci. 2020;93:1167-79.

8. Varela LG, Lucchi A, Bagnoli B, Nicolini G, loriatti C. Impacts of standard wine-making process on the survival of Lobesia botrana larvae (Lepidoptera: Tortricidae) in infested grape clusters. J Econ Entomol. 2013;106:2349-53.

9. Gutierrez AP, Ponti L, Gilioli G, Baumgärtner J. Climate warming effects on grape and grapevine moth (Lobesia botrana) in the Palearctic region. Agric For Entomol. 2018;20:255-71. https://doi.org/10.1111/afe.12256.

10. Altimira F, Vitta N, Tapia E. Integrated pest management of Lobesia botrana with microorganism in vineyards: an alternative for clean grapes production. IntechOpen. 2021. https://doi.org/10.5772/intechopen. 99153.

11. Dagatti CV, Becerra VC. Ajuste de modelo fenológico para predecir el comportamiento de Lobesia botrana (Lepidoptera: Tortricidae) en un viñedo de Mendoza, Argentina. Rev Soc Entomol Argent. 2015;74(3-4):117-22.

12. Satar G, Aslan MM, Ücük C. Two haplotypes of Lobesia botrana (Denis \& Schiffermüller, 1775) predominate in two adjacent regions of southern Turkey. Phytoparasitica. 2020;48:149-58.

13. Tasin M. Sex, wine and chemical communication in grapevine moth Lobesia botrana. PhD Dissertation, Swedish University of Agricultural Sciences, Acta Universitalis Agriculturae Sueciae, Alnarp, Sweden; 2005.

14. Yacoub A, Gerbore J, Magnin N, Chambon P, Dufour MC, Corio-Costet MF, et al. Ability of Pythium oligandrum strains to protect Vitis vinifera $\mathrm{L}$. by inducing plant resistance against Phaeomoniella chlamydospora, a pathogen involved in Esca, a grapevine trunk disease. Biol Control. 2016:92:7-16

15. Mondello V, Songy A, Battiston E, Pinto C, Coppin C, Trotel-Aziz P, et al. Grapevine trunk diseases: a review of fifteen years of trials for their control with chemicals and biocontrol agents. Plant Dis. 2018;102(7):1189-217.

16. Bertsch C, Ramírez-Suero M, Magnin-Robert M, Larignon P, Chong J, Abou-Mansour E, et al. Grapevine trunk diseases: complex and still poorly understood. Plant Pathol. 2013;62(2):243-65.

17. Vassiliou VA. Control of Lobesia botrana (Lepidoptera: Tortricidae) in vineyards in Cyprus using the mating disruption technique. Crop Prot. 2009:28:145-50.

18. Hofstetter V, Buyck B, Croll D, Viret O, Couloux A, Gindro K. What if esca disease of grapevine were not a fungal disease? Fungal Divers. 2012;54(1):51-67.

19. Fontaine F, Gramaje D, Armengol J, Smart R, Nagy ZA, Borgo M, et al. Grapevine trunk diseases. A review. Paris: OIV Publications; 2016;24. ISBN: 979-10-91799-60-7.ffhal-01604038f.

20. Ioriatti C, Anfora G, Angeli G, Mazzoni V, Trona F. Effects of chlorantraniliprole on eggs and larvae of Lobesia botrana (Denis \& Schiffermüller) (Lepidoptera: Tortricidae). Pest Manag Sci. 2009;65(6):717-22.

21. Lance DR, Leonard DS, Mastro VC, Walters ML. Mating disruption as a suppression tactic in programs targeting regulated lepidopteran pests in US. J Chem Ecol. 2016:42(7):590-605.

22. Ioriatti C, Anfora G, Tasin M, De Cristofaro A, Witzgall P, Lucchi A. Chemical ecology and management of Lobesia botrana (Lepidoptera: Tortricidae). J Econom Entomol. 2011;104(4):1125-37.

23. Louis F, Schmidt-Tiedemann A, Schirra KJ. Control of Sparganothis pilleriana Schiff. and Lobesia botrana Den. \& Schiff. in German vineyards using sex pheromone-mediated mating disruption. IOBC/WPRS Bull. 2002:25:1-9.

24. Lucchi A, Sambado P, Royo ABJ, Bagnoli B, Conte G, Benelli G. Disrupting mating of Lobesia botrana using sex pheromone aerosol devices. Environ Sci Pollut Res. 2018:25(22):22196-204. 
25. Geiger F, Bengtsson J, Berendse F, Weisser WW, Emmerson M, Morales $M B$, et al. Persistent negative effects of pesticides on biodiversity and biological control potential on European farmland. Basic Appl Ecol. 2010;11(2):97-105.

26. Hallenbeck WH, Cunningham-Burns KM, editors. Pesticides and human health. Berlin: Springer-Verlag New York; 2012. p. 159.

27. Glare T, Caradus J, Gelernter W, Jackson T, Keyhani N, Köhl J, et al. Have biopesticides come of age? Trends Biotechnol. 2012;30(5):250-8.

28. Araújo JP, Hughes DP. Diversity of entomopathogenic fungi: which groups conquered the insect body? Adv Genet. 2016;94:1-39.

29. Cuthbertson AG, Audsley N. Further screening of entomopathogenic fungi and nematodes as control agents for Drosophila suzukii. Insects. 2016:7(2):24.

30. Khater HF. Ecosmart biorational insecticides: alternative insect control strategies. In: Advances in integrated pest management. Croatia: InTech; 2011. p. 17-60.

31. Yun HG, Kim DJ, Gwak WS, Shin TY, Woo SD. Entomopathogenic fungi as dual control agents against both the pest Myzus persicae and phytopathogen Botrytis cinerea. Mycobiology. 2017;45(3):192-8.

32. Aguilera Sammaritano J, Deymié M, Herrera M, Vazquez F, Cuthbertson A, López-Lastra C, et al. The entomopathogenic fungus, Metarhizium anisopliae for the European grapevine moth, Lobesia botrana Den. \& Schiff. (Lepidoptera: Tortricidae) and its effect to the phytopathogenic fungus, Botrytis cinerea. Egypt J Biol Pest Control. 2018. https://doi.org/10. 1186/s41938-018-0086-4

33. Kang BR, Han JH, Kim JJ, Kim YC. Dual biocontrol potential of the entomopathogenic fungus, Isaria javanica, for both aphids and plant fungal pathogens. Mycobiology. 2018;46(4):440-7.

34. Barra-Bucarei L, France Iglesias A, Gerding González M, Silva Aguayo G, Carrasco-Fernández J, Castro JF, et al. Antifungal activity of Beauveria bassiana endophyte against Botrytis cinerea in two solanaceae crops. Microorganisms. 2020;8(1):65.

35. Ali S, Zhang C, Wang Z, Wang XM, Wu JH, Cuthbertson AG, et al. Toxicological and biochemical basis of synergism between the entomopathogenic fungus Lecanicillium muscarium and the insecticide matrine against Bemisia tabaci (Gennadius). Sci Rep. 2017;7(1):1-14.

36. Meyling NV. Methods for isolation of entomopathogenic fungi from the soil environment. Department of Ecology (Frederiksberg Denmark University of Copenhagen). 2007;1-18. http://www.orgprints.org/11200.

37. Bridge PD, Williams MAJ, Prior C, Paterson RRM. Morphological, biochemical and molecular characteristics of Metarhizium anisopliae and $M$. flavoviride. Microbiology. 1993;139(6):1163-9.

38. Aguilera Sammaritano JA, López Lastra CC, Leclerque A, Vazquez F, Toro ME, D'Alessandro C, et al. Control of Bemisia tabaci by entomopathogenic fungi isolated from arid soils in Argentina. Biocontrol Sci Technol. 2016;26(12):1668-82.

39. Delbac L, Thiery D. Damage to grape flowers and berries by Lobesia botrana larvae (Denis \& Schiffernüller) (Lepidoptera: Tortricidae), and relation to larval age. Aust J Grape Wine Res. 2016;22(2):256-61.

40. Ferreira A, Bastos M, Aguiar A. Criaçao de traça da uva Lobesia botrana Den. y Schiff. In: Actas do VI En-contro Nacional de Protecçao Integrada. Castelo Branco; 2003. p. 83-88

41. Herrera ME, Dagatti CV, Becerra VC. Método práctico de cría masiva de Lobesia botrana Den. \& Schiff. (Lepidoptera: Tortricidae) en condiciones de laboratorio. Rev Soc Entomol Argent. 2016;75(3-4):160-4.

42. García-Jiménez J, Vicent A, Armengol J. Las enfermedades de madera en vid, un problema creciente. Vida Rural. 2002;146:32-6.

43. White PJ, Brown PH. Plant nutrition for sustainable development and global health. Ann Bot. 2010;105(7):1073-80.

44. Munkvold GP. Eutypa dieback of grapevine and apricot. Plant Health Prog. 2001;2(1):9.

45. Rosa-Manzano MB, Pildain MB, Pappano DB, Rajchenberg M. Aislamiento e identificación de Eutypella microtheca (9287) en vides de la provincia de San Juan con síntomas de hoja de malvón (\#A2-024). In: $4^{\circ} \mathrm{Congreso}$ Argentino de Fitopatología. Mendoza, Argentina; 2017. http://aafitopato logos.com.ar/wp/wp-content/uploads/2017/06/Libro-de-res\%C3\% BAmenes-4\%C2\%B0-CAF.pdf?05a317.

46. Lecuona RE, Turica M, Tarocco F, Crespo DC. Microbial control of Musca domestica (Diptera: Muscidae) with selected strains of Beauveria bassiana. J Med Entomol. 2005;42(3):332-6.
47. Gołębiowski M, Bojke A, Tkaczuk C. Effects of the entomopathogenic fungi Metarhizium robertsii, Metarhizium flavoviride, and Isaria fumosorosea on the lipid composition of Galleria mellonella larvae. Mycologia. 2021;113(3):525-35. https://doi.org/10.1080/00275514.2021.1877520.

48. Reinert JA, Knauf TA, Maranz SJ, Bishr M. Effect of Beauveria bassiana fungus on the boxelder and red shouldered bugs (Hemiptera: Rhopalidae). Fla Entomol. 1999:82(3):469-74. https://doi.org/10.2307/3496873.

49. Trissi AN, El Bouhssini M, Al Salti MN, Abdulhai M, Skinner M, Parker BL. Virulence of Beauveria bassiana against Sunn pest, Eurygaster integriceps Puton (Hemiptera: Scutelleridae) at different time periods of application. Entomol Nematol. 2012;4(5):49-53.

50. Klingen I, Westrum K, Meyling NV. Effect of Norwegian entomopathogenic fungal isolates against Otiorhynchus sulcatus larvae at low temperatures and persistence in strawberry rhizospheres. Biol Control. 2015;81:1-7. https://doi.org/10.1016/j.biocontrol.2014.10.006.

51. Yu D, Xie R, Wang Y, Xie T, Xu L, Huang B. The G-protein coupled receptor GPRK contributes to fungal development and full virulence in Metarhizium robertsii. J Invertebr Pathol. 2021;83: 107627. https://doi.org/10. 1016/j.jip.2021.107627.

52. Kim JC, Lee MR, Kim S, Park SE, Lee SJ, Shin TY, Kim WJ, Kim J. Transcriptome analysis of the Japanese pine sawyer beetle, Monochamus alternatus, infected with the entomopathogenic fungus Metarhizium anisopliae JEF-197. J Fungi. 2021;7:373. https://doi.org/10.3390/jof7050373.

53. Li J, Xie J, Zeng D, Xia Y, Peng G. Effective control of Frankliniella occidentalis by Metarhizium anisopliae CQMa421 under field conditions. J Pest Sci. 2020;94(1):111-7. https://doi.org/10.1007/s10340-020-01223-9.

54. Hicks B. Optimization of Beauveria bassiana in a spray formulation against Choristoneura fumiferana. Can J For Res. 2016;46(4):543-7. https://doi.org/ 10.1139/cjfr-2015-0435.

55. Altimira F, De La Barra N, Rebufel P, Soto S, Soto R, Estay P, et al. Potential biological control of the pupal stage of the European grapevine moth Lobesia botrana by the entomopathogenic fungus Beauveria pseudobassiana in the winter season in Chile. BMC Res Notes. 2019;12(1):1-6.

56. Güven Ö, Aydin T, Karaca I, Butt T. Biopesticides offer an environmentally friendly solution for control of pine processionary moth (Thaumetopoea wilkinsoni Tams) larvae and pupae in urban areas. Biocontrol Sci Technol. 2020;31(1):35-52. https://doi.org/10.1080/09583157.2020.1826905.

57. Thiéry D, Monceau K, Moreau J. Larval intraspecific competition for food in the European grapevine moth Lobesia botrana. Bull Entomol Res. 2014;104(4):517-24

58. Abbott WS. A method of computing the effectiveness of an insecticide. J Econ Entomol. 1925;18(2):265-7.

59. Nally MC, Pesce VM, Maturano YP, Muñoz CJ, Combina M, Toro ME, et al. Biocontrol of Botrytis cinerea in table grapes by non-pathogenic indigenous Saccharomyces cerevisiae yeasts isolated from viticultural environments in Argentina. Postharvest Biol Technol. 2012;64(1):40-8.

60. Jiang C, Shi J, Liu Y, Zhu C. Inhibition of Aspergillus carbonarius and fungal contamination in table grapes using Bacillus subtilis. Food Control. 2014:35(1):41-8.

61. Di Rienzo JA, Casanoves F, Balzarini MG, Gonzalez L, Tablada M, Robledo CW. InfoStat versión 2020. Centro de Transferencia InfoStat, FCA, Universidad Nacional de Córdoba, Argentina. 2020. http://www.infostat.com.ar.

62. Ullah Ml, Altaf N, Afzal M, Arshad M, Mehmood N, Riaz M, et al. Effects of entomopathogenic fungi on the biology of Spodoptera litura (Lepidoptera: Noctuidae) and its reduviid predator, Rhynocoris marginatus (Heteroptera: Reduviidae). Int J Insect Sci. 2019;11:1179543319867116.

63. Schapovaloff ME, Alves LFA, Fanti AL, Alzogaray RA, López Lastra CC, Ode P. Susceptibility of adults of the cerambycid beetle Hedypathes betulinus to the entomopathogenic fungi Beauveria bassiana, Metarhizium anisopliae, and Purpureocillium lilacinum. J Insect Sci. 2014. https://doi. org/10.1093/jis/14.1.127.

64. Gutierrez AC, Gołębiowski M, Pennisi M, Peterson G, García JJ, Manfrino $R G$, et al. Cuticle fatty acid composition and differential susceptibility of three species of cockroaches to the entomopathogenic fungi Metarhizium anisopliae (Ascomycota, Hypocreales). J Econ Entomol. 2015;108(2):752-60.

65. López-Plantey R, Papura D, Couture C, Thiéry D, Pizzuolo PH, Bertoldi MV, et al. Characterization of entomopathogenic fungi from vineyards in Argentina with potential as biological control agents against the European grapevine moth Lobesia botrana. BioControl. 2019;64(5):501-11. 
66. Contreras J, Mendoza JE, Martinez-Aguirre MR, Garcia-Vidal L, Izquierdo J, Bielza P. Efficacy of entomopathogenic fungus Metarhizium anisopliae against Tuta absoluta (Lepidoptera: Gelechiidae). J Econ Entomol. 2014;107(1):121-4.

67. García GC, González MMB, Bautista MN. Patogenicidad de aislamientos de hongos entomopatógenos contra Spodoptera frugiperda (Lepidoptera: Noctuidae) y Epilachna varivestis (Coleoptera: Coccinellidae). Rev Colomb Entomol. 2011;37(2):217.

68. Sowjanya-Sree K, Padmaja V, Murthy YL. Insecticidal activity of destruxin, a mycotoxin from Metarhizium anisopliae (Hypocreales), against Spodoptera litura (Lepidoptera: Noctuidae) larval stages. Pest Manag Sci. 2008:64(2):119-25.

69. Zafar J, Shoukat RF, Zhang Y, Freed S, Xu X, Jin F. Metarhizium anisopliae challenges immunity and demography of Plutella xylostella. Insects. 2020;11(10):694.

70. Cozzi G, Somma S, Haidukowski M, Logrieco AF. Ochratoxin A management in vineyards by Lobesia botrana biocontrol. Toxins. 2013;5(1):49-59

71. Gholizad LM, Inan C, Nalçacioğlu R, Hamzezadeh A, Demirbağ Z. Bacterial flora of Lobesia botrana ([Denis \& Schiffermüller]) (Lepidoptera: Tortricidae) as a possible microbial control agent. Acta Zool Bulg. 2017;69(4):583-91.

72. Ekesi S, Maniania NK. Susceptibility of Megalurothrips sjostedti developmental stages to Metarhizium anisopliae and the effects of infection on feeding, adult fecundity, egg fertility and longevity. Entomol Exp Appl. 2000;94(3):229-36.

73. Tavassoli M, Ownag A, Pourseyed SH, Mardani K. Laboratory evaluation of three strains of the entomopathogenic fungus Metarhizium anisopliae for controlling Dermanyssus gallinae. Avian Pathol. 2008;37(3):259-63.

74. Bugeme DM, Knapp M, Boga HI, Ekesi S, Maniania NK. Susceptibility of developmental stages of Tetranychus urticae (Acari: Tetranychidae) to infection by Beauveria bassiana and Metarhizium anisopliae (Hypocreales: Clavicipitaceae). Int J Trop Insect Sci. 2014;34(3):190-6.

75. Vey A, Fargues J. Histological and ultrastructural studies of Beauveria bassiana infection in Leptinotarsa decemlineta larvae during ecdysis. J Invertebr Pathol. 1977;30(2):207-15. https://doi.org/10.1016/00222011(77)90221-x

76. Vestergaard S, Gillespie AT, Butt TM, Schreiter G, Eilenberg J. Pathogenicity of the hyphomycete fungi Verticillium lecanii and Metarhizium anisopliae to the western flower thrips, Frankliniella occidentalis. Biocontrol Sci Technol. 1995;5(2):185-92.

77. Rodríguez M, Gerding M, France A, Ceballos R. Metarhizium anisopliae var. anisopliae Qu-M845 isolate to control Varroa destructor (Acari: Varroidae) in laboratory and field trials. Chil J Agric Res. 2009;69(4):541-7. https://doi. org/10.4067/s0718-58392009000400009.

78. Lobo LS, Rodrigues J, Luz C. Effectiveness of Metarhizium anisopliae formulations against dengue vectors under laboratory and field conditions. Biocontrol Sci Technol. 2016;26(3):386-401. https://doi.org/10.1080/ 09583157.2015 .1123220$.

79. Keyser CA, Fernandes ÉKK, Rangel DEN, Foster RN, Jech LE, Reuter KC, et al. Laboratory bioassays and field-cage trials of Metarhizium spp. isolates with field-collected Mormon crickets (Anabrus simplex). BioControl. 2017;62(2):257-68. https://doi.org/10.1007/s10526-016-9782-8.

80. Singh $\mathrm{H}$, Joshi N. Management of the aphid, Myzus persicae (Sulzer) and the whitefly, Bemisia tabaci (Gennadius), using biorational on capsicum under protected cultivation in India. Egypt J Biol Pest Control. 2020;30(67):1-9. https://doi.org/10.1186/s41938-020-00266-5.

81. Brancini GT, Bachmann L, Braga GÚL. Timing and duration of light exposure during conidia development determine tolerance to ultraviolet radiation. FEMS Microbiol Lett. 2021. https://doi.org/10.1093/femsle/ fnab133.

82. Nguyen HQ, Quyen DT, Nguyen SLT, Van Hanh VU. An extracellular antifungal chitinase from Lecanicillium lecanii: purification, properties, and application in biocontrol against plant pathogenic fungi. Turk J Biol. 2015;39(1):6-14.

83. Lozano-Tovar MD, Garrido-Jurado I, Quesada-Moraga E, Raya-Ortega MC, Trapero-Casas A. Metarhizium brunneum and Beauveria bassiana release secondary metabolites with antagonistic activity against Verticillium dahliae and Phytophthora megasperma olive pathogens. Crop Prot. 2017;100:186-95.
84. Ownley BH, Griffin MR, Klingeman WE, Gwinn KD, Moulton JK, Pereira RM. Beauveria bassiana: endophytic colonization and plant disease control. J Invertebr Pathol. 2008;98(3):267-70.

85. Goettel MS, Koike M, Kim JJ, Aiuchi D, Shinya R, Brodeur J. Potential of Lecanicillium spp. for management of insects, nematodes and plant diseases. J Invertebr Pathol. 2008;98(3):256-61.

86. Shin TY, Bae SM, Woo SD. Screening and characterization of antimicrobial substances originated from entomopathogenic fungi. J Asia-Pac Entomol. 2016;19(4):1053-9.

\section{Publisher's Note}

Springer Nature remains neutral with regard to jurisdictional claims in published maps and institutional affiliations.
Ready to submit your research? Choose BMC and benefit from:

- fast, convenient online submission

- thorough peer review by experienced researchers in your field

- rapid publication on acceptance

- support for research data, including large and complex data types

- gold Open Access which fosters wider collaboration and increased citations

- maximum visibility for your research: over $100 \mathrm{M}$ website views per year

At BMC, research is always in progress.

Learn more biomedcentral.com/submissions 